\title{
Use of Allium cepa L. for assessment of toxicity of drinking water
}

\author{
E. Arystarkhova, \\ Candidate of Biological Sciences, \\ Institute of Agroecology and Environmental Management of NAAS
}

The purpose. To improve Allium test (biotest with onion), which is aimed at revealing toxicity of water, due to reduction of time of exposition of bulbuses and drop of labour input of testing. Methods. Temperature stimulation of body height of leaves of onion and biotesting toxicity of drinking water on standard and own procedures. Results. Stimulation of growth processes of plants which was carried out before testing, promoted increase of selfdescriptiveness of biotest (in particular, decrease by $66,67 \%$ of duration of exposition at fixation of root formation) and had allowed to lower its labour input (owing to simplification of determination of the test-reactions of onion). Conclusions. Assessment of toxicity of drinking water with the use of onion should be used after 14-days temperature stimulation of body height of leaves with the help of test-reactions root formation (by quantity of bulbuses from root fascicle after 1-day exposition) and creation of leaves (by quantity of bulbuses with grown leaves after 2-day exposition).

Key words: toxicity of drinking water, Allium test, temperature stimulation, root formation, leaf formation, index of toxicity, sharp toxic effect.

Assessing the quality of drinking water with the help of biological research methods is now extremely relevant. This is due to the peculiarities of secondary pollution of water during its decontamination and discoloration in the conditions of water and wastewater treatment plants. It is recognized that the physical and chemical analysis does not provide complete information on the overall toxicity of water [1-5]. Therefore, in addition to the use of analytical methods of research, it is recommended to include bioassay as a method for calculating the integral indicator of drinking water quality - the toxicity index, which is proposed to be determined by the reactions of individual animal test objects (daphnia, infusoria, etc.) [6]. However, it is known that animal and plant organisms can react differently to the same components of water [4, 5, 7]. Therefore, it is expedient to test drinking water on plants at the same time as animal models. The most suitable in this respect is the onion bioteth (Allium cepa L.). Proposed in 1937 and subsequently upgraded, this test was used for a long time to detect the toxicity of sewage and contaminated natural waters, and in recent decades, due to a significant deterioration in the status of water supply sources, it was also used to determine the quality of drinking water [ 8].

The disadvantage of biotest is that according to the standard the most effective is the detection of acute water toxicity within 3-5 days, which is associated with the physiological peculiarities of the formation of the onion root system, the growth inhibition of which was taken as the main test-reaction. These terms are not entirely consistent with biotesting in unified organisms of lower crustaceans (daphnia and ceriodophyans), which are the most common among animal test objects in biotesting drinking water [9], and on which it is possible to test drinking water for 1-2 days [10] In this regard, it is necessary to improve the technique of conducting a bioteth on the onion, adapting it to the specified terms.

Purpose - To improve the Allium test (onion biotest), designed to detect water toxicity, by reducing the time of exposure to bulbs and reducing the labor intensity of testing.

Materials and methods of research. The assessment of acute toxicity of drinking water that was cleaned at the Municipal Enterprise "Zhytomyrvodokanal" was carried out in September 2014 on the basis of biota on the onion of the Stuttgart Rizen variety, the method of which was improved. For this purpose, the same bulbs of the same size $(n=200)$ were kept in a dry room in transparent chemical containers $\left(0.5 \mathrm{dm}^{3}\right)$ under temperature stimulation $\left(20 \pm 2.5^{\circ} \mathrm{C}\right)$ and natural light to leaf regrowth for 14 days. From them, the bulbs-analogues (with leaf lengths of $3 \pm 0.5 \mathrm{~cm}$ ) were selected for formation of three 
experimental groups, each of which $(n=20)$ was subsequently subjected to action of drinking water of different quality. Immediately before the biotesting, the greasy leaves were cut to the base of the bulbs, as well as they were deprived of single dry roots present on individual plants. Young roots on the onion during germination of leaves did not appear.

Instead of measuring the length of individual roots, the number of bulbs with well-formed root bean and adults after the leaves were cut for the first and second day were determined in order to shorten the timing of testing and reduce its labor intensity, which is extremely relevant in the conditions of vodcasts and treatment plants. The data obtained in the trial were compared with the control.

Water samples, selected in the amount of $1 \mathrm{dm} 3$ per group according to generally accepted methods [6, $10]$, were tested in chemical containers $(0,5 \mathrm{dm} 3)$, in which daily water was replaced with water of appropriate quality.

The research was carried out according to the following scheme:

Control group - sample of dechlorinated (24 hours) tap water.

Test group D1: water samples- from CWR $5000 \mathrm{~m}^{3}$.

Test group D2: water samples - from CWR $20000 \mathrm{~m}^{3}$.

Biotesting - by the number of bulbs with the formed root bean (not less than $10 \mathrm{~mm}$ ) on the first day and growing after cutting the leaves (not less than $5 \mathrm{~mm}$ ) the second day.

Testing objects: onion (A. cepa).

The toxicity index of potable water was calculated based on the results of bioassay:

$\mathrm{T}=\left(\mathrm{I}_{\mathrm{K}}-\mathrm{I}_{\mathrm{o}}\right) 100 / \mathrm{I}_{\mathrm{K}}$,

where: $\mathrm{T}$ - toxicity index, \%;

$I_{K}$ - the value of test-reaction of onion on the control;

$\mathrm{I}_{0}$ - the value of the test-reaction of the onion in the test.

The toxicity index of drinking water should not exceed $50 \%[8,10]$.

Results. Determining the acute toxicity of potable water on unified plant test facilities during the first two days is more problematic than animal ones, as the standard conditions for bioassay for inhibition of the growth of onions roots are three to five days. And testing within five days is considered the most effective [4]. Therefore, in order to detect the acute effect of drinking water earlier, it was necessary to intensify the processes of plant growth and development. To do this, we proposed to carry out temperature stimulation $\left(20 \pm 2,5^{\circ} \mathrm{C}\right)$ for 14 days for germination of onion leaves at the condition of their root system in anabolic state. Thanks to this they received plants with different lengths of leaves. Among them, selected bulbs, which were analogues not only in size, but also in the speed of leaf formation.

The results of studies on the toxicity of drinking water due to root and leaf formation in the onion, which turned out to be quite informative indicators and allowed to improve the effectiveness of biotesting and simultaneously reduce the time spent on its conduct, is reflected in the Tables $1 \mathrm{i} 2$.

Table 1. Biotesting toxicity of drinking water by definition of root formation in A. cepa

\begin{tabular}{|c|c|c|c|c|c|c|}
\hline \multirow{4}{*}{$\begin{array}{l}\text { Testing date / } \\
\text { water toxicity index }(T)\end{array}$} & \multicolumn{6}{|c|}{ Number of onions $(n=20)$ : } \\
\hline & \multirow{2}{*}{\multicolumn{2}{|c|}{ Control Group (K) }} & \multicolumn{4}{|c|}{ Test Group } \\
\hline & & & \multicolumn{2}{|c|}{ D1 (CWR 5000) } & \multicolumn{2}{|c|}{ D2 (CWR 20000) } \\
\hline & pcs. & $\%$ & pcs. & $\%$ & pcs. & $\%$ \\
\hline 1 & 18 & 90 & 8 & 40 & 9 & 50 \\
\hline$T_{1}$ & & & \multicolumn{2}{|l|}{55} & \multicolumn{2}{|l|}{50} \\
\hline $\begin{array}{l}\text { with an underdeveloped root } \\
\text { bundle }\end{array}$ & 2 & 10 & 10 & 50 & 8 & 40 \\
\hline with no root bundle & - & - & 2 & 10 & 1 & 5 \\
\hline 2 & 20 & 100 & 12 & 60 & 14 & 70 \\
\hline $\mathrm{T}_{2}$ & & & \multicolumn{2}{|l|}{40} & \multicolumn{2}{|l|}{30} \\
\hline $\begin{array}{l}\text { with an underdeveloped root } \\
\text { bundle }\end{array}$ & - & - & 8 & 40 & 6 & 30 \\
\hline
\end{tabular}


The data obtained in the studies showed that the temperature stimulation of the growth of the onion leaves, carried out just before the bioassay, contributed to faster formation of the root beams than in the standard biota ( $66.67 \%$ in the first day). Reducing the labor intensity of the test was due to the application of root-formation as a test reaction, which is much simpler to determine the indices: the number of bulbs with a normally formed root system and the number of bulbs with an underdeveloped or absent root bundle. In the Allium test, you need to measure the length of each root, which takes much longer. In addition, if on nongerminated bulbs the biotesting of water toxicity during the first day is little informative, as a result of germination of the leaves, the growth processes of not only leaf formation but also root formation, which was demonstrated after the transfer of bulbs in water samples, was intensified.

The best conditions for growth and development of the onion root system were observed on the control (Table 1). In experimental groups, the number of bulbs with poorly developed root bundle at the end of the first week of research was 4-5 times higher. On the second day of testing, the underdeveloped root system in the control group was absent, and in experimental groups, the violation of the formation of the root beam was observed in $30-40 \%$ of bulbs.

Water toxicity indexes, determined during the first day of research, showed acute toxic effects (50-55\%) of drinking water from the CWR of Municipal Company "Zhytomyrvodokanal". On the second day of testing, the sensitivity of the root system of onion to the toxic effect of water decreased by $15-20 \%$. That is, the components of water (mainly chlorinated compounds, including chloroform) not so much delayed the growth of the roots, as contributed to the violation of the formation of root bundle of bulbs. Most likely, the violation of the onion root system also occurred on the cytological, genomic and / or genetic levels. Especially under similar conditions, there is no need to waste time measuring the length of each root, and it is more advisable to identify changes that can be used to detect cytological and genetic toxicity of drinking water.

Conducting a standard Allium test does not involve the use of test-response of plants to sheet formation [4], since its duration is $3-5$ days, and the onion leaves begin to germinate one week after the beginning of testing the quality of water. For the improvement of biota, the temperature stimulation of the bulbs has allowed to accelerate the growth of leaves. For research, plants with a leaf length of $3 \pm 0.5 \mathrm{~cm}$ were selected. Water toxicity testing was carried out after cutting the leaves and transferring the bulbs to a sample with water.

The reaction of leaf formation to the second day of plant research revealed a high sensitivity to the toxicity of drinking water. It was found that the toxicity indexes, calculated for the first day of biotesting, had only a tendency to increase, and in the second day almost reached the dangerous limit of 45-50\% (Table 2).

Table 2. Біотестування токсичності питної води за визначенням листоутворення у А. сера

\begin{tabular}{|c|c|c|c|c|c|c|}
\hline \multirow{4}{*}{$\begin{array}{l}\text { Testing date / } \\
\text { water toxicity index }(\mathrm{T})\end{array}$} & \multicolumn{6}{|c|}{ Number of onions $(n=20)$ : } \\
\hline & \multirow{2}{*}{\multicolumn{2}{|c|}{ Control Group (K) }} & \multicolumn{4}{|c|}{ Test Group } \\
\hline & & & \multicolumn{2}{|c|}{ D1 (CWR 5000) } & \multicolumn{2}{|c|}{ D2 (CWR 20000) } \\
\hline & pcs. & $\%$ & pcs. & $\%$ & pcs. & $\%$ \\
\hline 1 & 16 & 80 & 9 & 45 & 10 & 50 \\
\hline$T_{1}$ & & & \multicolumn{2}{|c|}{43,75} & \multicolumn{2}{|c|}{37,50} \\
\hline $\begin{array}{l}\text { with damaged development of } \\
\text { leaves }\end{array}$ & - & - & 2 & 10 & 2 & 10 \\
\hline with no leaves & 4 & 20 & 9 & 45 & 8 & 40 \\
\hline 2 & 20 & 100 & 10 & 50 & 11 & 55 \\
\hline$T_{2}$ & & & \multicolumn{2}{|l|}{50} & \multicolumn{2}{|l|}{45} \\
\hline $\begin{array}{l}\text { with damaged development of } \\
\text { leaves }\end{array}$ & - & - & 3 & 15 & 2 & 10 \\
\hline with no of leaves & - & - & 7 & 35 & 7 & 35 \\
\hline
\end{tabular}

The components of drinking water had little effect on breaking the leaf formation of onions. In a significant number of bulbs from experimental groups, unlike the control, there was a delay in leaf growth. The second day of testing for the control of such plants was not detected at all, and in experimental groups their share 
was $35 \%$ in each. Consequently, the test reactions of the onion root and leaf formulation can be used to biotest water toxicity for 1-2 days only under conditions of preliminary temperature stimulation of plants.

The use of simpler benchmarks in determining the usual onion test reactions allowed to improve the Allium toxicity test for potable water, which greatly simplified the technique, reduced the timing and expanded the possibilities of bioassay compared with other plant reactions used to assess the risk of water hazard. Thus, the determination of test reactions reflecting the formation of the root beam and the formation of leaves on the quantitative and qualitative composition of the bulbs is more suitable for calculating the water toxicity index than the traditional measurement of the length of all the roots of each bulb. This approach allows relatively fast, within two days, to detect an acute toxic effect of water, which is well consistent with testing on lower crustaceans (daphnia and ceriodophia) [10-11]. Under these conditions, improved onion biteotes will be more effective in a standardized test kit than standard.

Thus, to assess the acute toxicity of drinking water, it is possible to use a test reaction of root formation in one day of biotesting and a test reaction of sheet formation in two days. In further studies, the root system and the onion leaves should also be used to detect the cytotoxicity of the water, since it consists of mutagens and carcinogens.

\section{Conclusions}

Estimation of toxicity of drinking water on onion is suggested after 14-day temperature stimulation $\left(20 \pm 2,5^{\circ} \mathrm{C}\right)$ of leaf growth using test-reactions of root formation (by the number of bulbs with the formed root bean with exposure of 1 day) and leaf formation (by the number of bulbs from growing leaves with an exposition of 2 days).

\section{Bibliography}

1. Пат. 10804 А Україна, МПК G 01 N 33/18; G 01 N 21/76. Спосіб комплексного визначення генетичної безпечності питної води / В.В. Гончарук; заявник та патентовласник В.В. Гончарук; заявл. 5.11.2015, опубл. 11.04.2016, Бюл. № 7.

2. Веялкина Н.Н. Цитогенетические характеристики тест-организмов в комплексной оценке токсичности методами биотестирования / Н.Н. Веялкина // Актуальные проблемы экологии - 2008: материалы Междунар. науч.-практ. конф., Гродно, 29-31 октября 2008 г.: ГрГУ им. Я. Купалы. Гродно: ГрГУ, 2008. - С. 128-132.

3. Malik A. Environmental Deterioration and Human Health: Natural and anthropogenic determinants / A. Malik, E. Grohmann, R. Akhtar. - Dordrecht Heidelberg, London, New York: Springer, 2014. - P. 8-25.

4. Скок С.В. Оцінювання якості питної води м. Херсона методом біотестування / С.В. Скок // Агроекологічний журнал. - 2015. - № 2. - С.26-30.

5. Осмалений М.С. Комплексна оцінка токсичності водних зразків за допомогою рослинних і тваринних тест-організмів / М.С. Осмалений, А.М. Головков, А.В. Нанієва, М.Р. Верголяс // Фактори експериментальної еволюції організмів. - 2015. - т.16. - С. 74-77.

6. ДСанПіН 2.2.4-171-10 «Гігієнічні вимоги до води питної, призначеної для споживання людиною» / № 452 / 17747. - МОЗ України. Державні стандартні норми та правила / [чинний від 1.07.2010р.]. - 50 с.

7. Аристархова Е.О. Особливості визначення токсичності питної води / Е.О. Аристархова // Агроекологічний журнал. - 2016. - № 3. - С.50-55.

8. Fiskesjo G. The Allium test - an alternative in environmental studies : the relative toxicity of metal irons // Mutation Res. 1988. - V.197. - P. 243-260.

9. Аристархова Е.О. Наукові основи створення системи біомоніторингу вод поверхневих джерел водопостачання // Вісник аграрної науки. - 2016. - № 11. - С. 60-65.

10. Цитофізіологічна експрес-оцінка токсичності води (Біотестування): СТП 17-08. Методика. Затв. Комунальним підприємством «Житомирводо-канал» [дійсний від 10.09 .2008 р.]. - Житомир, 2008. $-15 \mathrm{c}$.

11. ДСТУ 4173-2003 (ISO 6341 : 1996, MOD). Визначення гострої летальної токсичності на Daphnia magna Straus i Ceriodaphnia affinis Lilljeborg (Cladosera, Crustacea). - Дійс. 3 2003-1-07. - К. : Держстандарт України. - 22 c. 